\title{
Levels of Free Granulocyte Elastase in Bronchial Secretions from Patients with Cystic Fibrosis: Effect of Antimicrobial Treatment Against Pseudomonas aeruginosa
}

S. Suter, U. B. Schaad, H. Tegner, K. Ohlsson, D. Desgrandchamps, and F. A. Waldvogel

\author{
From the Department of Pediatrics and the Division of \\ Infectious Diseases, University of Geneva, Geneva; the \\ Department of Pediatrics, University of Bern, Bern, \\ Switzerland; and the Department of Surgical \\ Pathophysiology, Malmö General Hospital,
} Malmö, Sweden
Individuals with cystic fibrosis suffer from a chronic infection of the airways characterized by progressive destruction of small bronchioles and later of large airways [1-3]. In these patients, colonization of the bronchial tree with Pseudomonas aeruginosa is related to the severity of the lung disease, as shown by deterioration of the clinical condition, radiographic findings, and lung function tests $[2,4]$. The mechanisms involved in bronchial and bronchiolar damage are not precisely known. However, evidence is accumulating that the local inflammatory reaction and immune response may be involved in tissue damage $[3,5,6]$. We have recently demonstrated that bronchial secretions from individuals with cystic fibrosis who are infected with $P$. aeruginosa contained large amounts of elastolytic activity attributable to granulocyte elastase (GE) [7]. GE is a potent proteolytic enzyme present in the primary granules of granulocytes [8]; it has proteolytic activity on structural proteins of the lung, such as elastin, collagen, and proteoglycan $[9,10]$. We further showed

Received for publication 9 September 1985, and in revised form 6 December 1985.

This work was supported by grants $3.816-0.84$ and $3.990-0.84$ from the Swiss Research Foundation.

Please address requests for reprints to Dr. S. Suter, Clinique Universitaire de Pédiatrie, 30, Boulevard de la Cluse, 1211-Geneva 4, Switzerland. that $P$ aeruginosa isolated from this group of patients with cystic fibrosis secreted in vitro bacterial elastase, an enzyme capable of inactivating $\alpha_{1}-$ proteinase inhibitor $\left(\alpha_{1}\right.$-PI) [11] and bronchial mucosal inhibitor (BMI) [12], which are the two main inhibitors protecting the lower and upper respiratory tract from the activity of GE $[9,13]$. The large amounts of free GE found in bronchial secretions from these subjects with cystic fibrosis could have resulted from an increased number of granulocytes (and, therefore, GE in the bronchial tree of these patients), a decreased local inhibitor potential for GE, or a combination of these two mechanisms.

In this study we evaluated the effect of iv antimicrobial therapy against $P$ seudomonas on activity and concentration of GE as well as on inhibitor activities and volumes of bronchial secretions of patients with cystic fibrosis who were infected with $P$ a aruginosa. Some individuals were followed up for three years. We also determined in vitro the effect of various inhibitors of GE [14-16] on the elastolytic activity of bronchial secretions from the subjects we studied.

\section{Subjects and Methods}

Twenty patients with cystic fibrosis were prospectively included in the study. The diagnosis of cystic 
fibrosis had been established on clinical features of the disease and was confirmed by sweat concentrations of $\mathrm{Na}^{+}$and $\mathrm{Cl}^{-}$of $>70 \mathrm{mEq} /$ liter. All patients were studied while they were hospitalized at Children's Hospital (University of Bern, Bern, Switzerland) for iv antimicrobial therapy. Their mean \pm SD age was $16.5 \pm 5$ years. They all had cultures of sputum positive for $P$. aeruginosa; two were also positive for Staphylococcus aureus. In total, 30 treatment courses were given to these 20 patients. The duration of therapy was 10-17 days (mean, 14 days). Netilmicin $(11 \mathrm{mg} / \mathrm{kg}$ per day) and in addition either azlocillin $(500 \mathrm{mg} / \mathrm{kg}$ per day) or ticarcillin (500 $\mathrm{mg} / \mathrm{kg}$ per day) were given for 14 days. Flucloxacillin was added for the patients infected with $S$. aureus at $150 \mathrm{mg} / \mathrm{kg}$ per day.

The following clinical and laboratory parameters were determined before initiation and at the end of antimicrobial therapy. All patients had a complete white blood cell count. Clinical and radiographic staging of cystic fibrosis was performed by one of us, unaware of the laboratory results, with use of a scoring system outlined previously [17]. This clini$\mathrm{cal} /$ radiographic scoring system included five parameters: physical activity, general physical condition and bacteriology of sputum, signs of pulmonary disease, radiological lung involvement, and gastrointestinal manifestations. Each parameter was rated on the basis of 1-5 points, with the highest score indicating the best status; thus the maximum clinical/radiographic score indicated the best status. The maximum score obtainable was therefore 25 . Severity of disease was graded into five stages (I-V). Radiographic scoring was performed with the scoring system of Chrispin and Norman [18]. The highest stage (V) corresponds to poor clinical condition and advanced radiographic alterations typical for cystic fibrosis.

Preparation of sputum samples. For the present study, sputum samples were analyzed as follows. Semiquantitative leukocyte counts were determined with standard methods [19] by using scores ranging from 1 to 4 . A score of 4 means $>25$ leukocytes per high-power field (magnification, 10) in each of five high-power fields examined; a score of 3 means 15-25 leukocytes under the same conditions. Sputum was inoculated onto blood, chocolate, and McConkey's agars, and identification of the pathogens was done with standard methods [20]. Fresh morning sputum obtained after chest physiotherapy was immediately mixed with an identical volume of sterile $0.9 \% \mathrm{NaCl}$ and centrifuged at $1,000 \mathrm{~g}$ until the supernatant was clear. The supernatants were stored at $-70 \mathrm{C}$ until tested. Their protein concentration was determined with a standard method (Biorad, Richmond, Calif). In 15 patients the 24 -hr sputum volume was measured before and after treatment.

Activities and concentration of $G E$. The elastolytic activity was measured according to the procedure of Hornebeck and Schnebli [21] with purified bovine elastin (Sigma, St. Louis) radiolabeled with ${ }^{3} \mathrm{H}$ (New England Nuclear Corp., Boston). Ten microliters of the test sample was incubated with 500 $\mu \mathrm{g}$ of $\left[{ }^{3} \mathrm{H}\right]$-elastin suspended in $0.1 M$ Tris buffer $(\mathrm{pH}$ 8.2) containing $0.01 \% 23$ lauryl ether (Brij ${ }^{\circledR 3}$; Sigma) and $0.02 \%$ sodium azide for $16 \mathrm{hr}$ at $37 \mathrm{C}$. The samples were then centrifuged at $3,300 \mathrm{~g}$ for 10 min. The radioactivity of $100 \mu$ l of the supernatant was measured and used to calculate the amount of solubilized elastin. One milligram of completely solubilized elastin corresponded to $145,000 \mathrm{cpm}$. Elastolytic activity (in UE) was expressed as milligrams of labeled elastin solubilized by $1 \mathrm{ml}$ of undiluted bronchial secretions.

GE-like activity was measured with use of the GEspecific substrate Suc-Ala-Ala-Pro-Val-7-amino-4methylcoumarin (Calbiochem-Behring, Lucerne, Switzerland). The sequence Ala-Ala-Pro-Val has been shown to be specific for GE [22]. Because the specificity of a small peptide substrate like the one that we used for a specific enzyme cannot be proven when working with biologic fluids, we chose the term GE-like. GE-like activity was expressed in UG $(\mu \mathrm{mol}$ of 7-amino-4-methylcoumarin liberated $/ \mathrm{min}$ by $1 \mathrm{ml}$ of enzyme solution at $30 \mathrm{C}$ [extinction coefficient, $12,300$ at $360 \mathrm{~nm}])$. The determinations were performed in a spectrophotometer (Beckman, Palo Alto, Calif) with thermostatted cuvettes and a continuous recording table.

Both enzymatic reactions measured were linear over the recording time.

The concentration of GE was determined in $\mathbf{3 0}$ paired samples with use of an RIA [23].

The elastolytic activity of $10 \mu \mathrm{g}$ of purified GE was $0.6 \mathrm{UE}$, and the GE-like activity was $0.055 \mathrm{UG}$ (means of triplicate determinations).

Purified human GE [24], a gift from Dr. H. P. Schnebli (Ciba-Geigy, Basel, Switzerland) was used as the standard. The elastolytic and GE-like activities of this amount of purified GE were inhibited by $98 \%$ and $100 \%$, respectively, when $2 \mathrm{mM}$ phenylmethylsulfonyl fluoride was used as inhibitor. 
Concentrations and activities of inhibitors. Concentrations of $\alpha_{1}$-PI and $\alpha_{2}$-macroglobulin $\left(\alpha_{2}-\mathrm{M}\right)$ were measured in 30 paired samples by radial immunodiffusion with use of Partigen ${ }^{\circledR}$ LC plates (Behringwerke, Marburg, Federal Republic of Germany). Samples were diluted appropriately, and concentrations were calculated from the linear regression coefficient with use of standards at five concentrations.

The concentration of BMI was measured as previously described [25].

To determine whether free active $\alpha_{1}$-PI or BMI was present in the bronchial secretions, we performed the following experiments. Crossed immunoelectrophoresis for $\alpha_{1}$-PI was done with a standard technique [26] with human serum as a control. The agarose gel (Seakem ${ }^{\circledR}$; batch 500 13; Marine Colloids, Rockland, Me) contained antiserum to $\alpha_{1}$-PI (Laboratory of the Department of Surgical Pathophysiology, Malmö General Hospital, Malmö, Sweden) [27]. Preand posttreatment samples of bronchial secretions were analyzed in the absence or presence of trypsin (Sigma) at six times the molar concentration of $\alpha_{1}$-PI.

In addition, 10 pre- and posttreatment bronchial secretions were pooled, and gel filtration was performed on a 1.6- $\times 100-\mathrm{cm}$ column of Sephadex ${ }^{\circledR}$ G-50 (Pharmacia Fine Chemicals, Uppsala, Sweden). The column was equilibrated with $0.05 M$ Tris$\mathrm{HCl}$ buffer (pH 7.4) containing $1.0 \mathrm{M} \mathrm{NaCl}$ and $0.005 M$ EDTA. Pooled bronchial secretions $(1.3 \mathrm{ml})$ were loaded on the column. The flow rate was 20 $\mathrm{ml} / \mathrm{hr}$ with a fraction volume of $4 \mathrm{ml} / \mathrm{hr}$. The fractions were analyzed for BMI, GE [23], and GE-like activity [22].

Inhibition experiments. The inhibitory effect of four inhibitors of GE on elastolytic and GE-like activity was measured: an oxidation-resistant variant of $\alpha_{1}$-PI [16] (the gift of Dr. Michael Courtney, Transgene SA, Strasbourg, France), partially purified $\alpha_{1}$ PI (Sigma), phenylmethylsulfonyl fluoride (Sigma), and eglin $\mathrm{C}$, a small polypeptide inhibitor specific for GE [15] (the gift from Dr. U. Seemüller, Institute for Clinical Chemistry, Munich). On each sample the inhibitory activity of $o$-phenantroline (Merck, Darmstadt, Federal Republic of Germany), an inhibitor of pseudomonas elastase [28], was also determined. The inhibitors and the enzyme solution were allowed to react for $1 \mathrm{~min}$ before the substrate was added. Inhibition was determined from the expression 100 - ([enzymatic activity of the sample with the inhibitor/enzymatic activity of the sample without the inhibitor $] \times 100$ ).
Statistical analysis. Data are expressed as mean \pm SD values. For comparisons of results before and after treatment, the Wilcoxon rank test was used. Correlations were calculated with use of Spearman's correlation coefficient, when scores were compared with laboratory results.

\section{Results}

Clinical and radiographic scores, white blood cell counts, and sputum leukocyte scores. Antimicrobial treatment resulted in significant improvement of clinical condition and radiographic findings, as determined by our scoring system. In 18 of the 30 treatment courses analyzed, treatment resulted in a decrease of one disease stage, and no change was observed in 12 treatment courses $(P<.001)$.

The mean white blood cell count decreased significantly from $13,524 \pm 4,585 / \mu 1$ before to 7,367 $\pm 2,897 / \mu \mathrm{l}$ after treatment $(P<.001)$. Despite a statistically significant decrease in the mean sputum leukocyte score $(P<.001)$ from a mean of 3.9 (range, $3-4)$ to 3.5 (range, 2-4) after treatment, none of the patients had a score of $<2$ after treatment.

Cultures of sputum. Cultures of sputum for $P$. aeruginos $a$ were negative at the end of treatment in 12 of 30 treatment courses. However, the cultures were positive for $P$. aeruginosa in all patients within one month after treatment.

The total sputum volume, in $\mathrm{ml} / 24 \mathrm{hr}$, decreased by $25 \%-90 \%$ at the end of treatment (mean, $60 \%$; $P<.001$ ).

Concentration and activities of elastase, concentrations and activities of inhibitors, and concentrations of total protein in sputum. Table 1 shows the results of sputum analysis before and after antimicrobial therapy. Of the levels of immunoreactive GE, elastolytic activity, and GE-like activity, only the decrease in level of immunoreactive GE was statistically significant $(P<.05)$ in a comparison of sample pairs.

In all sputum samples tested in this study, elastolytic activity was inhibited by $>85 \%$ with $2 \mathrm{mM}$ phenylmethylsulfonyl fluoride, an inhibitor of serine proteases such as GE, but not by $10 \mathrm{mMo}$-phenantroline, an inhibitor of $P$. aeruginosa elastase [28]. This observation confirms that elastolytic activity in these sputum samples did not derive from $P$. aeruginosa elastase or macrophage elastase [29], the third elastase possibly involved in elastolytic activity.

Table 1 also shows the concentrations of the in- 
Table 1. Results of sputum analysis before and after antimicrobial therapy.

\begin{tabular}{|c|c|c|c|c|}
\hline \multirow[b]{2}{*}{ Parameter } & \multicolumn{2}{|c|}{ Antimicrobial therapy } & \multirow{2}{*}{$\begin{array}{c}\text { No. of } \\
\text { pairs tested }\end{array}$} & \multirow[b]{2}{*}{$P^{*}$} \\
\hline & Before & After & & \\
\hline \multicolumn{5}{|l|}{ Enzymatic activity } \\
\hline Elastolytic activity (UE) & $2.1 \pm 1.1$ & $2.4 \pm 1.7$ & 30 & NS \\
\hline GE-like activity (UG) & $0.64 \pm 0.62$ & $0.75 \pm 0.62$ & 30 & NS \\
\hline $\mathrm{GE}(\mu \mathrm{g} / \mathrm{ml})$ & $89.7 \pm 52.4$ & $63.7 \pm 32.0$ & 15 & $<.05$ \\
\hline \multicolumn{5}{|l|}{ Inhibitor concentration } \\
\hline$\alpha_{1}-\mathrm{PI}(\mathrm{mg} / \mathrm{g}$ of protein) & $6.3 \pm 6.0$ & $11.4 \pm 7.1$ & 15 & $<.05$ \\
\hline$\alpha_{2}-\mathrm{M}(\mathrm{mg} / \mathrm{g}$ of protein) & $7.4 \pm 5.6$ & $6.9 \pm 5.5$ & 15 & NS \\
\hline BMI (ng/mg of protein) & $223 \pm 204$ & $927 \pm 2,231$ & 15 & .05 \\
\hline $\begin{array}{l}\text { Total protein concentration } \\
\text { (g/liter) }\end{array}$ & $10.3 \pm 6.2$ & $9.1 \pm 5.3$ & 30 & NS \\
\hline
\end{tabular}

NOTE. Data are mean \pm SD values. $N S=$ not significant.

* By Wilcoxon rank test.

hibitors $\alpha_{1}-\mathrm{PI}, \alpha_{2}-\mathrm{M}$, and $\mathrm{BMI}$ in sputum before and after therapy. The differences in levels of $\alpha_{1}$-PI and BMI were statistically significant $(P<.05$ and $P$ $=.05$, respectively).

The difference in the concentration of total protein in sputum before and after therapy was not significant (table 1).

When levels of free GE determined as elastolytic activity inhibited by $2 \mathrm{mM}$ phenylmethylsulfonyl

Table 2. Levels of free elastase and immunoreactive GE in cystic fibrotic sputum samples before and after antimicrobial therapy.

\begin{tabular}{rcrrr}
\hline & \multicolumn{2}{c}{$\begin{array}{c}c \\
\text { elastase }(\mu \mathrm{g} / \mathrm{ml})\end{array}$} & \multicolumn{2}{c}{$\begin{array}{c}\text { Immunoreactive } \\
\text { GE }(\mu \mathrm{g} / \mathrm{ml})\end{array}$} \\
\cline { 2 - 5 } Subject no. & Before & After & Before & After \\
\hline 1 & 20 & 20 & 60 & 48 \\
2 & 47 & 28 & 84 & 104 \\
3 & 38 & 36 & 200 & 52 \\
4 & 36 & 43 & 96 & 66 \\
5 & 19 & 6 & 28 & 9 \\
6 & 18 & 132 & 47 & 124 \\
7 & 35 & 28 & 60 & 42 \\
8 & 16 & 64 & 76 & 124 \\
9 & 62 & 28 & 90 & 60 \\
10 & 66 & 45 & 94 & 74 \\
11 & 87 & 71 & 200 & 108 \\
12 & 40 & 21 & 74 & 50 \\
13 & 16 & 6 & 19 & 62 \\
14 & 30 & 8 & 76 & 11 \\
\hline
\end{tabular}

NOTE. The level of free elastase was determined by measurement of elastolytic activity with purified GE as the standard. The elastolytic activity was inhibited by $89 \%-98 \%$ by $2 \mathrm{mM}$ phenylmethylsulfonyl fluoride, which characterizes it as a serine protease such as GE. The level of immunoreactive GE was determined as described by Ohlsson and Olsson [23]. fluoride were expressed as $\mu \mathrm{g}$ of GE, the concentration of immunoreactive GE always exceeded the levels of free elastase except in one sample (table 2). In the other 29 samples, free elastase represented from $13 \%$ to $84 \%$ of the immunoreactive GE. On crossed immunoelectrophoresis, $\alpha_{1}$-PI was shown to migrate in two peaks (figure 1) within the bronchial secretions. The migration pattern of $\alpha_{1}$-PI in human serum is shown for comparison (figure 1, top). The first peak corresponds to $\alpha_{1}$-PI not bound to elastase, but it migrates slightly differently than unaltered $\alpha_{1}$ PI. The second, smaller peak corresponds to $\alpha_{1}$-PI complexed with elastase (figure 1 , middle). When the cystic fibrotic bronchial secretion was allowed to react with an excess of trypsin, no trypsin-reactive $\alpha_{1-}$ PI was found (figure 1, bottom), a result suggesting that all of the immunoreactive $\alpha_{1}$-PI was present in an inactive form.

Also, the gel filtration of 13 pooled samples of sputum showed that most of the BMI was found in the fraction corresponding to the complex between BMI and GE. Free elastase was found in the corresponding fraction (data not shown), but no free BMI could be demonstrated.

Inhibition of elastolytic activity of cystic fibrotic sputum by the oxidation-resistant variant of $\alpha_{1}-P I$, partially purified $\alpha_{1}-P I$, and eglin $C$ in vitro. The calculated elastase content of $10 \mu \mathrm{l}$ of cystic fibrotic sputum varied from 0.06 to $1.32 \mu \mathrm{g}$ of GE. The mean inhibition of the elastolytic activity of $10 \mu \mathrm{l}$ of cystic fibrotic sputum was $73 \%$ (range, $46 \%-95 \%$ ) in the presence of $5 \mu \mathrm{g}$ of the oxidation-resistant variant of $\alpha_{1}$-PI $(n=10)$ and $89 \%$ (range, 61\%-100\%) with $50 \mu \mathrm{g}$ of partially purified $\alpha_{1}$-PI $(n=27)$. The 50 


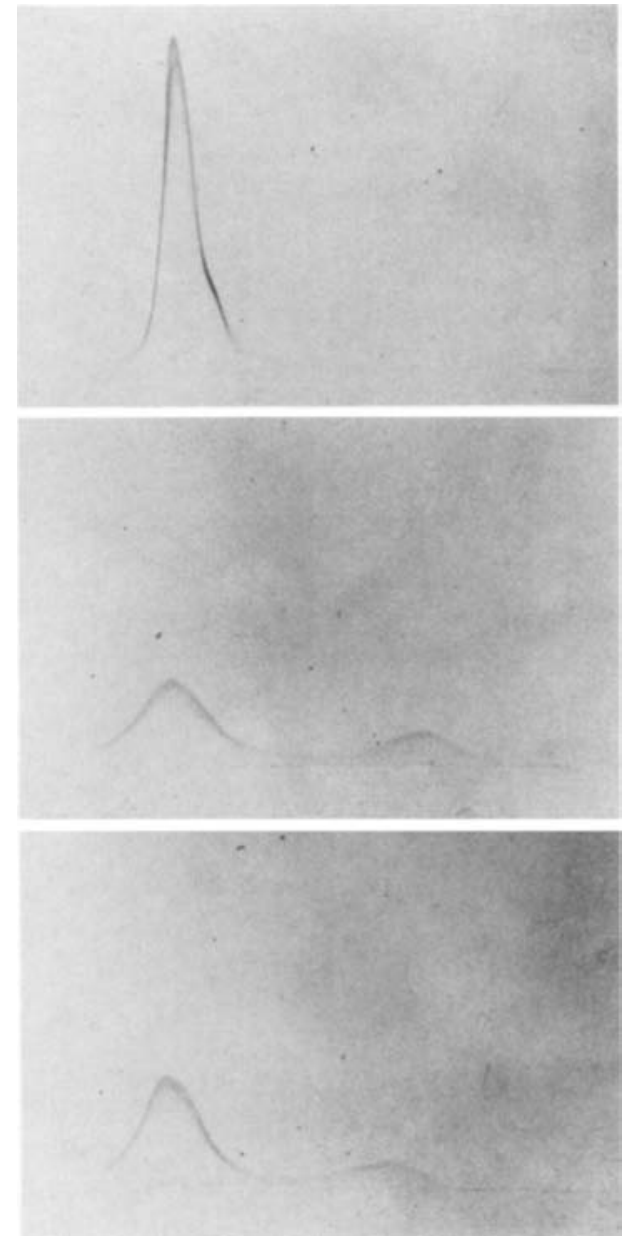

Figure 1. An example of the migration pattern of $\alpha_{1}$-PI in $100 \mu \mathrm{l}$ of a cystic fibrotic bronchial secretion on crossed immunoelectrophoresis. The cathode is at the left, and the anode is at the right. The agarose gel, which contained antiserum to $\alpha_{1}$-PI, shows the migration pattern of (top, a) $\alpha_{1}$-PI in human serum, (middle, $b$ ) $\alpha_{1}-\mathrm{PI}$ in an untreated bronchial secretion, and (bottom, c) $\alpha_{1}$-PI in a bronchial secretion in the presence of trypsin at six times the molar concentration of $\alpha_{1}$-PI. There is a small peak at the right, which corresponds to $\alpha_{1}-\mathrm{PI}$ bound to enzyme, and a larger peak at the left, which migrates slightly differently from $\alpha_{1}$-PI in serum. The presence of $\alpha_{1}$-PI that does not react with trypsin and migrates differently from enzyme-bound $\alpha_{1}$-PI indicates that this peak corresponds to inactive, unbound $\alpha_{1}$-PI. This trypsin-unreactive $\alpha_{1}$-PI also migrates slightly differently from $\alpha_{1}$-PI in human serum.

$\mu \mathrm{g}$ of this preparation of $\alpha_{1}$-PI corresponded to $\sim 5$ $\mu \mathrm{g}$ of completely purified $\alpha_{1}$-PI. When $10 \mu \mathrm{g}$ of eglin $\mathrm{C}$ was used to inhibit the elastolytic activity of 10 $\mu l$ of cystic fibrotic sputum $(n=27)$ it resulted in a mean inhibition of $35 \%$ (range, $0 \%-64 \%$ ), whereas $100 \mu \mathrm{g}$ of eglin $C(n=9)$ resulted in a mean inhibi- tion of $74 \%$ (range, $58 \%-95 \%$ ). In comparison, the elastolytic activity of $1.57 \mu \mathrm{g}$ of purified GE, which had an elastolytic activity slightly higher than the amounts of cystic fibrotic sputum samples tested, was inhibited by $98 \%$ with $5 \mu \mathrm{g}$ of the oxidationresistant mutant of $\alpha_{1}$-PI and with $50 \mu \mathrm{g}$ of partially purified $\alpha_{1}$-PI, by $83 \%$ with $10 \mu \mathrm{g}$ of eglin $\mathrm{C}$, and by $95 \%$ with $100 \mu \mathrm{g}$ of eglin $\mathrm{C}$. These results show that the amount of inhibitor required for inhibition of elastolytic activity of cystic fibrotic sputum samples is higher than the amount needed to inhibit the elastolytic activity of purified GE.

Correlations of clinical and radiographic scores and the age of the patients with elastolytic activity of sputum samples. A highly significant correlation was found when elastolytic activity of sputum samples before and after treatment was compared with disease stages. High elastolytic activity of sputum samples correlated with high disease stages $\left(r_{s}\right.$ $=.98, P<.001)$.

\section{Discussion}

In this group of patients with cystic fibrosis who were infected with $P$. aeruginosa, the clinical and pulmonary condition, as determined by a five-stage scoring system, improved significantly after antimicrobial treatment. The level of total immunoreactive GE, which represents free and inhibitor-bound GE, decreased significantly, and levels of immunoreactive $\alpha_{1}-\mathrm{PI}$ and the BMI, the main inhibitors of GE in the respiratory tract, increased (table 1). Despite this decrease in the total GE content, which was important because sputum volume had also decreased significantly, free elastolytic activity per milliliter of sputum remained elevated. We calculated that the mean concentration of GE in this group of patients was $55 \mu \mathrm{g} / \mathrm{ml}$ of sputum, which corresponds to the elastase content of $1.5 \times 10^{7}$ granulocytes [8]. Thus the airways of these patients were continuously exposed to free GE. In addition, we always observed a gradual increase in sputum volume during the treatment-free intervals in those patients followed up prospectively for three years. These findings are clearly different from what was observed in adults with chronic bronchitis and bronchiectases, in whom elastolytic activity of sputum was significantly lower than in patients with cystic fibrosis [7]. Also, in adults with chronic bronchitis, antimicrobial therapy for acute exacerbation was found to lead to a decrease in elastolytic activity [30]. 
Until now, most studies reporting free elastolytic activity in sputum were restricted to patients with cystic fibrosis who were infected with $P$. aeruginosa $[7,31-33]$, and the patients were not followed up prospectively for longer periods. In several studies $[7,32,33]$ elastolytic activity in cystic fibrotic sputum was shown to derive mainly from GE and not from $P$. aeruginosa elastase, with the exception of one report [31] in which the results from experiments with inhibitors suggested that $P$. aeruginos elastase might contribute to the elastolytic activity measured. In addition to our patients with cystic fibrosis who were infected with $P$. aeruginosa, we also measured levels of free GE in the bronchial secretions of six patients with cystic fibrosis who were not infected with $P$. aeruginosa. Sputum from five patients colonized with $S$. aureus contained levels of free GE from 10 to $32 \mu \mathrm{g} / \mathrm{ml}$. In secretions aspirated from the left mainstem bronchus of a one-year-old girl with cystic fibrosis who was infected with Escherichia coli, we measured a level of $40 \mu \mathrm{g} / \mathrm{ml}$, and in secretions from the bronchus of the right lower lobe, which was the main focus of chronic infection in this child, we found a concentration of $140 \mu \mathrm{g}$ of free $\mathrm{GE} / \mathrm{ml}$. Thus the presence of large amounts of GE in the airways of these subjects may precede the onset of colonization with $P$. aeruginosa. In all individuals colonized with $P$. aeruginosa, we found that advanced disease stage correlated with high elastolytic activity of sputum. It is important to note that this observation does not mean that there is a causal relationship between these two parameters, but rather it is a demonstration of a correlation of pronounced inflammation with advanced disease stages.

What are the possible causes in individuals with cystic fibrosis for this persistent imbalance between GE and its main antiproteases? The high levels of immunoreactive GE (table 2), which always exceeded those of free elastase except in one sample, clearly show that excessive numbers of granulocytes were present in the airways of these patients and that the amount of released GE may have exceeded the local inhibitor potential. In addition, oxidants released by granulocytes during phagocytosis may inactivate the elastase inhibitory capacity of $\alpha_{1}$-PI [34]. In the present study we also tried to define in vivo the role of $P$. aeruginosa elastase, which in vitro has proteolytic activity on a series of proteins involved in inflammatory reactions and the immune response $[7,11$, $12,35,36]$. We found no evidence that BMI was inactivated by $P$. aeruginosa elastase in the sputum of our patients with cystic fibrosis because gel filtration of sputum samples showed that all the BMI was bound to GE. (Since the submission of this report, this finding has also been confirmed in another study [32].) On the basis of our experiments, we conclude that the $\alpha_{1}$-PI in cystic fibrotic bronchial secretions was present in inactive forms only, but we can not distinguish whether $\alpha_{1}$-PI was inactivated by oxidants [34] or $P$. aeruginosa elastase. On crossed immunoelectrophoresis, the $\alpha_{1}$-PI in an untreated bronchial secretion (figure 1, middle) migrated slightly differently from the $\alpha_{1}$-PI in serum (figure 1, top). When the same bronchial secretion was allowed to react with trypsin before immunoelectrophoresis (figure 1 , bottom), no trypsin-reactive $\alpha_{1}$-PI was found. A small amount of enzyme-bound $\alpha_{1}$-PI was also detectable.

That the large numbers of granulocytes and the high levels of free GE are most likely involved in tissue damage in individuals with cystic fibrosis is suggested by several other studies. In a recent report [33] biochemical and pathological evidence for proteolytic destruction of lung connective tissue in cystic fibrosis due to elastase was presented. Furthermore, the tissue-damaging effects of granulocyte proteases as well as oxidants, which may be released from granulocytes, were well documented in experimental models [37], and the substrate spectrum of GE includes elastin, collagen, and proteoglycan $[9,10]$, all three of which are important structural proteins of the lung. In addition, GE also has proteolytic activity on opsonins such as C3 [7] in cystic fibrotic bronchial secretions as well as on immunoglobulins in vitro $[38,39]$. Fragmentation of IgG into fragments resembling those generated by GE were demonstrated in bronchial secretions in cystic fibrosis [33]; however, in a subsequent report, these authors presented evidence that $P$. aeruginos $a$ elastase in vitro may also be involved in IgG cleavage [36]. At present, cleavage of IgG by $P$. aeruginosa elastase within the bronchial tree of patients with cystic fibrosis has not been demonstrated. In other chronic pyogenic infections such as pleural empyema caused by a variety of bacterial pathogens, proteolysis of $\mathrm{C} 3$ was due to GE [40], and fragmentation of immunoglobulins was also observed [41]. Thus the precise role that $P$. aeruginosa elastase plays in vivo in individuls with cystic fibrosis who are infected with this pathogen remains to be established.

Taken together, our observations and those of others suggest that in cystic fibrosis, GE may con- 
tribute to tissue damage as well as microbial persistence by proteolytic degradation of opsonins. Inhibition of GE by synthetic inhibitors of this enzyme potentially may prevent airway damage. We tested two inhibitors of GE for their potential to inhibit elastolytic activity of cystic fibrotic bronchial secretions in vitro. Eglin C, a synthetic GE inhibitor [15], and an oxidation-resistant mutant of $\alpha_{1}$-PI [16] both substantially suppressed elastolytic activity of cystic fibrotic bronchial secretions in vitro. The elastolytic activity of purified GE was inhibited to a greater extent by both inhibitors than was that of bronchial secretions, a phenomenon that may be due to binding of these inhibitors to enzmes or proteins other than GE. Eglin C was shown to be devoid of toxicity in an experimental animal model [42], and both compounds are currently produced by recombinant DNA technology $[16,43]$ and may in the future be available for clinical studies.

In summary, the clinical and pulmonary condition of our patients with cystic fibrosis who were infected with $P$. aeruginosa was significantly improved by iv antimicrobial therapy against $P$. aeruginosa. A transient eradication of the organism from sputum was obtained in 12 of 30 treatment courses, and the sputum volume per 24-hr interval decreased transiently. However, in all bronchial secretions studied, including those of six patients who were not colonized with $P$. aeruginosa, high levels of free GE were found. Before as well as after treatment in the patients infected with $P$. aeruginos $a, \alpha_{1}-\mathrm{PI}$ and BMI were found in inactive forms. These high levels of free granulocyte neutral proteases in the airways persisted for prolonged periods, and high proteolytic activity correlated with advanced pulmonary disease. Because in vitro elastolytic activity of cystic fibrotic bronchial secretions was due to GE and was substantially inhibited by eglin $C$ and an oxidation-resistant variant of $\alpha_{1}$-PI, we suggest that these compounds, as soon as they have been shown to be devoid of toxicity, be evaluated for their potential of preventing progressive airway damage in individuals with cystic fibrosis, in addition to appropriate antimicrobial therapy.

\section{References}

1. Sant'Agnese PAD. Cystic fibrosis. In: Vaughan VC, McKay RJ, Behrman RE, eds. Nelson textbook of pediatrics. 1lth ed. Philadelphia: Saunders, 1979:1988-2001

2. Pennington JE, Wolff SM, Puziss M. Summary of a work- shop on infections in patients with cystic fibrosis. J Infect Dis 1979;140:252-6

3. Marks MI. The pathogenesis and treatment of pulmonary infections in patients with cystic fibrosis. J Pediatr 1981; 98:173-9

4. Høiby N, Flensborg EW, Beck B, Friis B, Jacobsen SV, Jacobsen L. Pseudomonas aeruginosa infection in cystic fibrosis: diagnostic and prognostic significance of Pseudomonas aeruginosa precipitins determined by means of crossed immunoelectrophoresis. Scand J Respir Dis 1977;58:65-79

5. Skov S, Norn S, Schiøtz PO, Permin H, Høiby N. Pseudomonas aeruginosa. Allergy in cystic fibrosis. Involvement of histamine release in the pathogenesis of lung tissue damage. Allergy 1980;35:23-9

6. Jacquot J, Tournier JM, Carmona TG, Puchelle E, Chazalette JP, Sadoul P. Proteins of bronchial secretions in cystic fibrosis. Role of infection. Clinical Respiratory Physiology 1983;19:453-8

7. Suter S, Schaad UB, Roux L, Nydegger UE, Waldvogel FA. Granulocyte neutral proteases and pseudomonas elastase as possible causes of airway damage in patients with cystic fibrosis. J Infect Dis 1984;149:523-31

8. Smolen JE, Weissman G. The granulocyte: metabolic properties and mechanisms of lysosomal enzyme release. In: Havemann K, Janoff A, eds. Neutral proteases of human polymorphonuclear leukocytes: biochemistry, physiology and clinical significance. Baltimore: Urban and Schwarzenberg, 1978:56-76

9. Gadek JE, Fells GA, Zimmerman RL, Rennard SI, Crystal RG. Antielastases of the human alveolar structures. Implications for the protease-antiprotease theory of emphysema. J Clin Invest 1981;68:889-98

10. Sandberg LB, Soskel NT, Leslie JG. Elastin structure, biosynthesis and relation to disease states. N Engl J Med 1981;304:566-79

11. Moskowitz RW, Heinrich G. Bacterial inactivation of human serum alpha-I antitrypsin. J Lab Clin Med 1971;77:777-85

12. Johnson DA, Carter-Harnm B, Dralle WM. Inactivation of human bronchial mucosal proteinase inhibitor by Pseudomonas aeruginosa elastase. Am Rev Respir Dis 1982; 126:1070-3

13. Hochstrasser K, Albrecht GJ, Schönberger OL,Rasche B, Lempart K. An elastase-specific inhibitor from human bronchial mucus: isolation and characterization. Hoppe Seylers Z. Physiol Chem 1981;362:1369-75

14. Ohlsson $K$. Alpha ${ }_{1}$-antitrypsin and alpha $a_{2}$-macroglobulin. Interactions with human neutrophil collagenase and elastase. Ann NY Acad Sci 1975;256:409-19

15. Seemüller U, Meier M, Ohlsson K, Müller HP, Fritz H. Isolation and characterization of a low molecular weight inhibitor (of chymotrypsin and human granulocyte elastase and cathepsin G) from leeches. Hoppe Seylers Z Physiol Chem 1977;358:1105-17

16. Courtney M, Jallat S, Tessier LH, Benavente A, Crystal RG, Lecocq JP. Synthesis in $E$. coli of $\alpha_{1}$-antitrypsin variants of therapeutic potential for emphysema and thrombosis. Nature 1985;313:149-51

17. Kraemer R, Tschäppeler H, Rüdeberg A, Stoll E, Rossi E. Verlauf und quantitative Erfassung des pulmonalen $\mathrm{Be}$ falls bei zystischer Fibrose. Schweiz Med Wochenschr 1979;109:39-45 
18. Chrispin AR, Norman AP. The systematic evaluation of the chest radiograph in cystic fibrosis. Pediatr Radiol 1974; 2:101-6

19. Bucher U. Die Sputumuntersuchung bei unspezifischen Krankheiten der tiefen Luftwege. Bern: Hans Huber Verlag, 1965:40-1

20. Washington JA. Laboratory procedures in clinical microbiology. New York: Springer Verlag, 1981

21. Hornebeck W, Schnebli HP. Effect of different elastase inhibitors on leukocyte elastase preadsorbed to elastin. Hoppe Seylers Z Physiol Chem 1982;363:455-8

22. Nakajima K, Powers JC, Ashe BM, Zimmerman M. Mapping the extended substrate binding site of cathepsin $\mathrm{G}$ and human leukocyte elastase. Studies with peptide substrates related to the $\alpha_{1}$-protease inhibitor reactive site. $J$ Biol Chem 1979;254:4027-32

23. Ohlsson K, Olsson AS. Immunoreactive granulocyte elastase in human serum. Hoppe Seylers Z Physiol Chem 1978; 359:1531-9

24. Baugh RJ, Travis J. Human leucocyte granule elastase: rapid isolation and characterization. Biochemistry 1976;15: $836-41$

25. Fryksmark U, Ohlsson K, Rosengren M, Tegner H. A radioimmunoassay for measurement and characterization of human antileukoprotease in serum. Hoppe Seylers Z Physiol Chem 1981;362:1273-7

26. Ganrot PO. Crossed immunoelectrophoresis. Scand J Clin Lab Invest [Suppl 124] 1972:29:39-47

27. Ballden G, Ohlsson K, Olsson AS. Studies on the influence of Trasylol on the partition of trypsin between the human plasma protease inhibitors in vitro. Hoppe Seylers $Z$ Physiol Chem 1978;359:691-7

28. Hudgin RL, Charleson SE, Zimmerman M, Mumford R, Wood PL. Enkephalinases: selective peptide inhibitors. Life Sci 1981;29:2593-601

29. Cohen AB. Potential adverse effects of lung macrophages and neutrophils. Fed Proc 1979;38:2644-7

30. Hill SL, Stockley RA, Bronchiectasis. Infection free or purulent free? Clin Sci 1982;62:389-99

31. Bruce MC, Ponz L, Klinger JD, Stern RC, Tomashefski JF, Dearborn DG. Biochemical and pathological evidence for proteolytic destruction of lung connective tissue in cystic fibrosis. Am Rev Respir Dis 1985;132:529-35

32. Tournier JM, Jacquot J, Puchelle E, Bieth JG. Evidence that Pseudomonas aeruginosa elastase does not inactivate the bronchial inhibitor in the presence of leucocyte elastase. Am Rev Respir Dis 1985;132:524-8
33. Fick RB, Naegel GP, Squier SU, Wood RE, Bernard J, Gee L, Reynolds HY. Proteins of the cystic fibrosis respiratory tract. Fragmented immunoglobulin $\mathrm{G}$ opsonic antibody causing defective opsonophagocytosis. J Clin Invest 1984; 74:236-48

34. Carp H, Janoff A. Potential mediator of inflammation. Phagocyte-derived oxidants suppress the elastase-inhibitory capacity of $\alpha_{1}$-proteinase inhibitor in vitro. J Clin Invest 1980;66:987-95

35. Schultz DR, Miller KD. Elastase of Pseudomonas aeruginosa: inactivation of complement components and complementderived chemotactic and phagocytic factors. Infect Immun 1974;10:128-35

36. Fick RB Jr, Baltimore RS, Squier SU, Reynolds HY. IgG proteolytic activity of Pseudomonas aeruginosa in cystic fibrosis. J Infect Dis 1985;151:589-98

37. Schraufstätter IU, Revak SD, Cochrane CG. Proteases and oxidants in experimental pulmonary inflammatory injury. J Clin Invest 1984;73:1175-84

38. Prince HE, Folds JD, Spitznagel JK. Proteolysis of human lgG by human polymorphonuclear leukocyte elastase produces an $\mathrm{Fc}$ fragment with in vitro biological activity. Clin Exp Immunol 1979;37:162-8

39. Prince HE, Folds JD, Spitznagel JK. Interaction of human polymorphonuclear leukocyte elastase with human IgM. In vitro production of an Fab $\mu$-like fragment. Mol Immunol 1979;16:301-6

40. Suter S, Nydegger UE, Roux L, Waldvogel FA. Cleavage of C3 by neutral proteases from granulocytes in pleural empyema. J Infect Dis 1981;144:499-508

41. Lew PD, Despont JP, Perrin LH, Aguado MT, Lambert PH, Waldvogel FA. Demonstration of a local exhaustion of complement components and of enzymatic degradation of immunoglobulins in pleural empyema: a possible factor favouring the persistence of local bacterial infections. Clin Exp Immunol 1980;42:506-14

42. Snider GL, Stone PJ, Lucey EC, Breuer R, Calore JD, Seshadri T, Catanese A, Maschler R, Schnebli HP. Eglin-C, a polypeptide derived from the medicinal leech, prevents human neutrophil elastase-induced emphysema and bronchial secretory cell metaplasia in the hamster. Am Rev Respir Dis 1985;132:1155-61

43. Rink H, Liersch M, Sieber P, Meyer F. A large-fragment approach to DNA synthesis: total synthesis of a gene for the protease inhibitor eglin $\mathrm{C}$ from the leech Hirudo medicinalis and its expression in E. coli. Nucleic Acids Res $1984 ; 12: 6369-87$ 